\title{
Evaluation of Clinicopathologic Features of Patients Diagnosed with Atypical Glandula Cells in Cervical Cytology
}

\author{
Servikal Sitolojide Atipik Glandüler Hücre Tanısı Konan Hastaların \\ Klinikopatolojik Özelliklerinin Değerlendirilmesi
}

\author{
Yusuf CAKMAK $\odot$, Duygu KAVAK COMERT $\odot$, Tufan OGE $\odot$, Ozgur Aydin TOSUN $\odot$, Isik SOZEN $\odot$
}

Ethics Committee Approval: This study approved by the Eskişehir Osmangazi University Ethics Committee for Clinical Studies (05 December 2018, 2018-14)

Conflict of interest: The authors declare that they have no conflict of interest.

Funding: None.

Informed Consent: Not Applicable.
Cite as: Cakmak Y, Kavak Comert D, Oge T, Tosun OA, Sozen I. Evaluation of clinicopathologic features of patients diagnosed with atypical glandulacells in cervical cytology. Medeniyet Med J. 2019;34:284-9.

\begin{abstract}
Objective: In our study we aimed to evaluate the clinicopathologic features of patients diagnosed with atyipcal glandular cells on cervical cytology.

Method: The records of 9375 patients who were examined in the gynecology outpatient clinic between 2010 and 2018 and underwent cervicovaginal smear were retrospectively reviewed. Seventy-three $(0.8 \%)$ patients were diagnosed as atypical glandular cells. Colposcopic examination, cervical biopsy, endocervical and endometrial curettage were performed in patients diagnosed with atypical glandular cells. Age, gravida, parity, systemic diseases and clinicopathological features of the patients were examined and recorded

Results: Cervical and endometrial abnormal histological findings were detected in 26 (35.6\%) of 73 patients with atypical glandular cells. Of these 26 patients, $14(19.1 \%)$ had cervical intraepithelial lesions, $3(4.1 \%)$ had endometrial hyperplasia and 9 (12.3\%) had invasive cancer. Five $(6.8 \%)$ of the 9 patients with the diagnosis of invasive cancer had adenocarcinoma (endocervical and endometrial), in $3(4.1 \%)$ patients cervical squamous carcinoma, and in 1 patient. endocervical lymphoma was observed.The majority of cancers detected in our study were in the age group of 50 years and older.

Conclusion: Invasive cancer is seen in $12.3 \%$ of the patients diagnosed with atypical glandular cells, and most of these patients are 50 years or older. Therefore patients diagnosed with atypical glandular cell in cervicovaginal smear should be carefully evaluated with all clinical features.
\end{abstract}

Keywords: Atypical glandular cell, cervical cytology, cervical premalignant lesion

Öz

Amaç: Çalışmamızda servikovajinal smear sonrası atipik glandüler hücre tanısı konan hastaların klinikopatolojik özelliklerini değerlendirmeyi amaçladık.

Yöntem: Kadın hastalıkları polikliniğinde 2010-2018 yılları arasında muayene edilen ve servikovajinal smear yapılan 9375 hastanın kayıtları retrospektif olarak incelendi. Yetmiş üç $(\% 0,8)$ hastaya atipik glanduler hücreler tanısı kondu. Atipik glandüler hücreler tanısı konulan hastalarda kolposkopik muayene, servikal biyopsi, endoservikal ve endometriyal küretaj yapıldı. Hastaların yaş, gravida, parite, sistemik hastalıklar ve klinikopatolojik özellikleri incelendi ve kaydedildi Bulgular: Atipik glandüler hücreli 73 hastanın 26'sında (\%35,6) servikal ve endometrial anormal histolojik bulgular saptandı. Bu 26 hastanın 14 'ünde $(\% 19,1)$ servikal intraepitelyal lezyon, 3 'ünde $(\% 4,1)$ endometrial hiperplazi, 9'unda $(\% 12,3)$ invaziv kanser mevcuttu. Invaziv kanser tanısı alan 9 hastanın beşinde $(\% 6,8)$ adenokarsinom (endoservikal ve endometrial), 3 'ünde $(\% 4,1)$ servikal skuamöz karsinom gözlendi. Bir hastada endoservikal lenfoma izlendi. Çalışmamızda tespit edilen kanserlerin büyük çoğunluğu 50 yaş ve üstü yaş grubundaydı.

Sonuç: Atipik glanduler hücre tanısı konan hastaların \%12.3 de invaziv kanser görülmektedir ve bu hastaların çoğunun yaşı 50 yaş ve üzeridir. Bu nedenle servikovaginal smear nedeniyle atipik glandüler hücre tanısı konan hastalar tüm klinik özelliklerle dikkatlice değerlendirilmelidir.

Anahtar kelimeler: Atipik glandüler hücre, servikal sitoloji, servikal premalign lezyon
Received: 8 July 2019

Accepted: 31 August 2019

Online First: 27 September 2019

Corresponding Author:

Y. Cakmak

ORCID: 0000-0003-3128-247X

Eskisehir Osmangazi University School of Medicine, Department of Obstetrics and Gynecology, Eskisehir, Turkey

dryusuf21@gmail.com

D. Kavak Comert

ORCID: 0000-0002-9977-6567 T. Oge

ORCID: 0000-0002-1951-9713

I. Sozen

ORCID: 0000-0002-7733-9171

Eskisehir Osmangazi University, School of Medicine, Department of Gynocology and Obstetrics, Eskisehir, Turkey

O.A. Tosun

ORCID: 0000-0001-8067-669X Istanbul University, School of Medicine, Department of Gynecology and Obstetrics, Istanbul, Turkey 


\section{INTRODUCTION}

Cervical cancer is the second most common gynecological cancer in developing countries ${ }^{1,2}$. Presence of a screening test and human papillomavirus (HPV) vaccine effects the incidence of cervical cancer. Screening programs can detect precancerous lesions which are treatable early stage cancers. Cervical cancer screening began with the development of the Papanicolaou (Pap) test which is routinely applied in many countries. The Bethesda System standardized the cervical cytology terms in $1988^{3}$. This system has been revised several times and the last review was made in 2014 $4^{4-6}$. Atypical glandular cells (AGC) exhibit reactive and restorative nuclear changes, but they have not fully features of invasive carcinoma. AGC were divided into four groups. These groups are AGC, AGC favor neoplastic, endocervical adenocarcinoma in situ (AIS) and adenocarcinoma. Atypical glandular cell endocervical, endometrial, or not otherwise specified (NOS) is noted as a subcategory. AGC replaces the previous term "atypical glandular cells of undetermined significance (AGUS).

Based on cervical cytology findings, AGC usually originate from the glandular epithelium of the endocervix or endometrium. AGC is found less commonly than abnormal squamous cells. Glandular abnormalities are found in approximately 0.1 to 2.1 percent of cervical cytology samples ${ }^{7}$. Women with atypical glandular cells require further evaluation for premalignant conditions of the cervix, uterus, and rarely, ovary.

AGC's histologic evaluation may identify normal findings or squamous or glandular lesions. Approximately $30 \%$ of AGC seems to be associated with premalignant and malignant lesions. Mostly squamous rather than glandular cells are detected upon histologic evaluation ${ }^{10-18}$. There are many risk factors for the development of premalignant and malignant diseases. These risk factors include high-risk HPV subtypes, age, gynecological history, immunodeficiency and socioeconomic sta- tus. Especially age is an important risk factor for the development of premalignant and malignant diseases ${ }^{14}$.

The initial evaluation of AGC should include colposcopic examination, cervical biopsy, endocervical and endometrial sampling for women over 35 years of age. Endometrial sampling is recommended in patients under 35 years of age who have complaints of abnormal menstrual bleeding ${ }^{19}$. All these diagnostic procedures pose a risk to the health of the patient and an economic burden. Therefore, in this study, we aimed to evaluate the clinicopathologic features of patients diagnosed with AGC in cervical cytology.

\section{MATERIAL and METHODS}

This study approved by the Eskişehir Osmangazi University Ethics Committee for Clinical Studies (5 December 2018, 2018-14).

The records of 9375 patients who were examined in the gynecology outpatient clinic between 2010 and 2018 and underwent cervicovaginal smear examination were retrospectively reviewed. Two hundred and fifty-one patients were excluded due to missing medical data records. A total of 9124 cervicovaginal smears were evaluated. Seventythree $(0.8 \%)$ patients were diagnosed as AGC. Files of patients diagnosed with AGC were retrospectively reviewed. Conventional Pap smear test method was used for cervical cytology. The patients were taken to the gynecologic table in the lithotomy position and the vulva, vagina and cervix were evaluated. In the smear procedure, endocervical brush was used and samples from squamocolumnar junction and endocervical canal were obtained. The cells on the brush were spread on the slide and fixed with 95\% ethyl alcohol and examined by a pathologist specialized in gynecology. After cervicovaginal smears of patients with AGC were evaluated according to the Bethesda classification system, they were referred for colposcopic examination. Colposcopy device 
with WelchAllyn brand number 13153 was used for colposcopic examination of patients. Three percent acetic acid and lugol solutions were used during the examination. During the procedure, paracervical block was applied with local injection of $5 \mathrm{ml}$ 2\% lidocaine solution. Cervical biopsy, endocervical and endometrial curettage were performed in adherence to the colposcopy guide. One patient underwent conization, whereas the remaining patients underwent total abdominal hysterectomy $(n=14)$ or radical hysterectomy $(n=2)$. Specimens obtained were evaluated by the same gynecological pathologist. Patients whose medical file could not be accessed or missing and patients who did not consent to diagnostic procedures were excluded from the study.

Age, gravida, parity, systemic diseases and clinicopathological features of the patients were examined and recorded. The ages of the patients with AGC were grouped in 10-year intervals starting from the age of 20. Distributions of the patients according to age groups were evaluated. Ethics committee approval was obtained for our study with the decision number 2018-294.

Data were analysed using IBM SPSS 21 package program. Summary values of quantitative data were shown as mean standard deviation (SD) or median (Q1-Q3). Summary values of qualitative variables are shown as frequency and percentage. The normal distribution of quantitative variables was investigated by Shapiro-Wilk test. Quantitative comparisons of two groups were performed by Mann-Whitney $U$ test. Results with $p<0.05$ were considered significant.

\section{RESULTS}

AGCs were detected in $73(0.8 \%)$ patients when cervicovaginal smear results were examined. The mean age $(42.64 \pm 10.2$ years), gravida $(3.25 \pm 1.7)$, and the parity $(2.4 \pm 1.1)$ of the patients diagnosed as AGC were also estimated. Sixty-two (84.9\%) patients with AGC were in the premenopausal and $11(15 \%)$ in the postmenopausal period. It was observed that $18(24.6 \%)$ patients had postcoital bleeding, 23 (31.5\%) had abnormal discharge and $44(60.2 \%)$ patients did not use contraceptive methods. Twenty-nine patients were using birth control methods. The patients were using intrauterine device (IUD) ( $n=14: 48.2 \%)$, condoms ( $n=10: 34.4 \%$ ) Mirena (52 mg levonorgestrel releasing IUD) $(n=1: 3 \%)$ and $4(13.7 \%)$ patients had their tubes ligated. The mean age of patients who had multiple births was 38 and they mostly preferred IUD Clinicopathologic features of patients are shown in Table 1.

When the patients diagnosed with atypical glan-

Table 1. Characteristic features (mean value) all patients (n:73).

\begin{tabular}{llll}
\hline Gravidy ( $\mathrm{n} \pm$ standart deviation) & $3.25 \pm 1.7$ & Not using contraception $\mathrm{n}(\%)$ & $44(60.2 \%)$ \\
Parity ( $\mathrm{n} \pm$ standart deviation) & $2.45 \pm 1.1$ & KT-RT story $\mathrm{n}(\%)$ & $9(9.5 \%)$ \\
Abortus( $\mathrm{n} \pm$ standart deviation) & $0.84 \pm 1.1$ & DM n (\%) & $6(8.2 \%)$ \\
Age (years \pm standart deviation) & $42.6 \pm 10.2$ & HT $\mathrm{n}(\%)$ & $3(4.1 \%)$ \\
Marriage duration(years \pm standart deviation) mean & $21.06 \pm 9.9$ & Hypothyroidism $\mathrm{n}(\%)$ & $3(4.1 \%)$ \\
Postcoital bleeding $\mathrm{n}(\%)$ & $18(24.6 \%)$ & Premenopausal $\mathrm{n}(\%)$ & $62(84.9 \%)$ \\
Abnormal cervical discharge $\mathrm{n}(\%)$ & $23(31.5 \%)$ & Postmenopausal $\mathrm{n}(\%)$ & $11(15 \%)$
\end{tabular}

DM: diabetes mellitus, HT: hypertansion

Table 2. Distribution of AGC patients according to age groups.

\begin{tabular}{|c|c|c|c|c|c|c|}
\hline Age groups & $20-29$ & $30-39$ & $40-49$ & $50-59$ & $60-69$ & 70-79 \\
\hline AGC n (\%) & $6(8.2 \%)$ & $22(30 \%)$ & 26 (35.6\%) & $14(19.1 \%)$ & $4(5.4 \%)$ & $1(1.3 \%)$ \\
\hline
\end{tabular}

AGC: Atypical glandular cell 
Table 3. Distribution of abnormal results according to age groups.

\begin{tabular}{|c|c|c|c|c|c|c|}
\hline Age groups & $20-29$ & $30-39$ & 40-49 & $50-59$ & $60-69$ & Total \\
\hline CIN 1 & 1 & 5 & 5 & & & $11(15 \%)$ \\
\hline CIN 2 & & 1 & 1 & & & $2(2.73 \%)$ \\
\hline CIN 3 & & & 1 & & & $1(1.36 \%)$ \\
\hline Endometrial hyperplasia & & & & 1 & 2 & $3(4.1 \%)$ \\
\hline Endometrial adenocarcinoma & & & & 3 & 1 & $4(5.4 \%)$ \\
\hline Cervical squamous carcinoma & & 1 & & 2 & & $3(4.1 \%)$ \\
\hline Endocervical adenocarcinoma & & & & 1 & & $1(1.36 \%)$ \\
\hline lymphoma & & & 1 & & & $1(1.36 \%)$ \\
\hline total & $1(1.36 \%)$ & $7(9.5 \%)$ & $8(10.9 \%)$ & $7(9.5 \%)$ & $3(4.1 \%)$ & $26(35.6 \%)$ \\
\hline
\end{tabular}

CIN: Cervical intraepithelial neoplasia

Table 4. Clinical features of tumour patients.

\begin{tabular}{|c|c|c|c|c|c|c|c|}
\hline No & Origin & Diagnosis & Colposcopy & First diagnosis & Age & Menopause & Stage $^{\&}$ \\
\hline 1 & Endometrium & Adenocarcinoma & Abnormal $^{*}$ & AGC & 50 & no & 1ag1 \\
\hline 2 & Endometrium & Adenocarcinoma & Insufficient & AGC & 52 & yes & 1ag1 \\
\hline 3 & Endometrium & Adenocarcinoma & Normal & AGC & 56 & yes & 3ag2 \\
\hline 4 & Endometrium & Adenocarcinoma & Abnormal* & AGC & 52 & yes & 1ag2 \\
\hline 5 & Cervical & Squamous & Abnormal $^{*}$ & $\mathrm{AGC}+\mathrm{HSIL}$ & 34 & no & $1 \mathrm{~b} 1$ \\
\hline 6 & Cervical & Squamous & Abnormal $^{*}$ & AGC & 50 & no & 1a1 \\
\hline 7 & Cervical & Squamous & Abnormal $^{*}$ & $\mathrm{AGC}+\mathrm{ASC}-\mathrm{H}$ & 57 & yes & $2 b$ \\
\hline 8 & Endocervical & Adenocarcinoma & Normal & AGC & 56 & yes & $1 \mathrm{~b}$ \\
\hline 9 & Endocervical & Lymphoma & Abnormal $^{*}$ & AGC & 44 & no & 4 \\
\hline
\end{tabular}

${ }^{*}$ Atypical vascularization, Asetowhite epithelium, Punctuation, Locoplaci, Mosaic; AGC: Atypical glandular cell, \&: Figo TNM Classification, HSIL: High grade squamous intraepithelial neoplasia, ASC-H: Atypical squamous cell-high grade squamous intraepithelial lesions cannot excluded.

dular cell were separated according to age range of 10 years, 26 (35.6\%) patients were in the age bracket of $40-49$ and $22(30 \%)$ of them in the age bracket of 30-39 years. The distribution of patients according to age groups is shown in Table 2 .

Cervical and endometrial abnormal histological findings were detected in 26 (35.6\%) of 73 patients with AGC. Of these 26 patients, 14 (19.1\%) had cervical intraepithelial lesions, 3 (4.1\%) endometrial hyperplasia and 9 (12.3\%) invasive cancer. In $5(6.8 \%)$ of 9 patients with the diagnosis of invasive cancer, adenocarcinoma (endocervical and endometrial), and in $3(4.1 \%)$ patients cervical squamous carcinoma was observed. The incidence rates of these lesions according to age groups are shown in Table 3.

Four of the invasive cancers detected in patients with AGC were endometrial origin, four were originated from cervix, and one was detected as metastasis to cervix. All patients diagnosed with endometrial adenocarcinoma were 50 years and older. Of the 4 cancers caused by cervix, only 1 patient is 34 years old and other patients are $\mathbf{5 0}$ years and older. One cervical lymphoma was also 44 years old.

In the patients with AGC, 1 patient was diagnosed as high grade squamous intraepithelial lesion (HSIL) and in 1 patient diagnosed as cervical squamous cell carcinoma, atypical squamous cellhigh grade squamous intraepithelial lesion cannot be excluded (ASC-H). Five (55\%) patients with invasive cancer were in postmenopausal period. Clinicopathologic features of patients with invasive cancer are shown in Table 4.

Colposcopic examination of patients with AGC was normal in 37 patients and pathological findings (acetowhite epithelium, punctuation, mosaic 
structure, etc.) were detected in 36 patients. No invasive cervical cancer was found in the group with normal findings. The histological biopsy results of the patients with normal colposcopic examination were reported as cervical intraepithelial neoplasia (CIN) 1 in 5, CIN 2 in 1 , endocervical adenocarcinoma in 1 , and endometrial cancer in 1 patient.

\section{DISCUSSION}

AGC is a less common lesion in cervicovaginal smears than squamous cell anomalies, but it should be evaluated carefully because of its relationship with precancerous and cancerous lesions. In our study, as a result of histopathological evaluation of patients diagnosed with AGC, cellular abnormalities were detected in $26(35.6 \%)$ patients. Nine (12.3\%) of these abnormal results were invasive cancer. Seven patients with invasive cancer consisted of patients aged 50 years and over.

In our study, 73 patients $(0.8 \%)$ were diagnosed with AGC. This ratio is consistent with the rates between $0.05 \%$ and $6 \%$ indicated in the literature review study of Marques JP et $\mathrm{al}^{7}$ in which 19 studies were examined in $2011^{23}$. In another literature study, the reported rate of AGC in cervical smears ranged from $0.08 \%$ to $2.5 \%$. When the patients were examined according to age groups of 10 years, it was observed that patients with AGC were most frequently seen in the age group of 40-49 years in accordance with the literature ${ }^{21}$. In the study of insignia RP et $\mathrm{al}^{20}$, squamous cellderived lesions were found to be higher in the 30-39 age group. The subsequent occurrence of cervical squamous lesions in our study may be related to differences in risk factors such as age at the onset of sexual intercourse, multipartner sexual intercourse and socioeconomic status.

Histological examination of AGC patients revealed premalignant and malignant lesions in 26 (35.6\%) patients. In the literature, this rate varies in a very wide range as $17-100 \% \%^{8-20,23,24}$. In the study of
Marques JP et $\mathrm{al}^{20}$ the average detection rate of abnormal lesion was $58 \%{ }^{7}$. In the study in which 622 AGC patients were evaluated, Zhao $\mathrm{C}$ et $\mathrm{al}^{14}$ abnormal lesion rate was found to be $15.3 \%$. In a study by Philip Castle et all ${ }^{1}$, detected abnormal lesions (excl. CIN1 lesion) in $18.1 \%$ of their patients. When the literature is reviewed, the extreme difference between the number of patients participating in the studies is remarkable. The risk factors for cervical and endometrial cancers vary among the centers. Therefore, the detection rate of abnormal lesion (35.6\%) in our study was consistent with the literature findings. In our study, 11 (15\%) patients with AGC had cervical CIN1 lesions and 3 (4.1\%) had CIN2-3 lesions. Cervical intraepithelial neoplasia occurs in $20-28 \%$ of the patients with AGC in the literature. In the literature, the detection rate of CIN2-3 lesion of is higher when compared with our study ${ }^{7,15,21}$. The difference in these rates may be related to the prevalence of risk factors for cervical intraepithelial lesions. Another reason for the differences between studies may be that the reproducibility rate in AGC and other diagnoses is different between observers $^{25}$.

In our study, invasive cancer was found in $12.3 \%$ of our patients. Adenocarcinomas, and squamous carcinoma accounted for $6.8 \%$, and $4.1 \%$ of the cases with invasive cancers, respectively. In contrast to preinvasive lesions, the rate of cancer with glandular origin is higher in invasive cancers in accordance with the literature 23,24 . The majority of cancers detected in our study were in the age group of 50 years and older 22,2 . In addition, squamous cell lesions were detected in cervical cytology in patients with cervical cancer.

There are some limitations of our study. Retrospective design of our study, its small sample size, lack of HPV vaccine history, and information about patients in subcategories of AGC were the weaknesses of the study. However, our sample size still gives some information about the clinical characteristics of patients diagnosed as AGC. 


\section{CONCLUSION}

Patients diagnosed with AGC based on histopathological examination of cervicovaginal smear samples should be carefully evaluated with all clinical features. Some (35.6\%) of these patients had precancerous and cancerous lesions and $12.3 \%$ of them had invasive cancer. Most cancer cases have been detected in patients 50 years and older.

\section{REFERENCES}

1. Siegel RL, Miller KD, Jemal A. Cancer statistics, 2019. CA Cancer J Clin. 2019;69:7-34. [CrossRef]

2. Torre LA, Bray F, Siegel RL, Ferlay J, Lortet-Tieulent J, Jemal A.Global cancer statistics, 2012. CA Cancer J Clin. 2015;65:87-108. [CrossRef]

3. The 1988 Bethesda system for reporting cervical/vaginal cytological diagnoses. National cancer institute workshop. JAMA. 1989;262:931-4. [CrossRef]

4. Broder S. From the national institutes of health. JAMA. 1992;267:1892. [CrossRef]

5. Solomon D, Davey D, Kurman R, et al. The 2001 Bethesda System: terminology for reporting results of cervical cytology. JAMA. 2002;287:2114-9. [CrossRef]

6. Nayar R, Wilbur DC. The Pap test and Bethesda 2014: "The reports of my demise have been greatly exaggerated. ( After a quotation from Mark Twain)". J Low Genit Tract Dis. 2015;19:175-84. [CrossRef]

7. Marques JP, Costa LB, Pinto AP, et al. Atypical glandular cells and cervical cancer: systematic review. Rev Assoc Med Bras (1992). 2011;57:229-34. [CrossRef]

8. Veljovich DS, Stoler MH, Andersen WA, Covell JL, Rice LW. Atypical glandular cells of undetermined significance: A five-year retrospective histopathologic study. Am J Obstet Gynecol. 1998;179:382-90. [CrossRef]

9. Geier CS, Wilson M, Creasman W. Clinical evaluation of atypical glandular cells of undetermined significance. Am J Obstet Gynecol. 2001;184:64-9. [CrossRef]

10. Eddy GL, Strumpf KB, Wojtowycz MA, Piraino PS, Mazur MT. Biopsy findings in five hundred thirty-one patients with atypical glandular cells of uncertain significance as defined by the Bethesda system. Am J Obstet Gynecol. 1997; 177:1 188-95. [CrossRef]

11. Chhieng DC, Elgert P, Cohen JM, Cangiarella JF. Clinical significance of atypical glandular cells of undetermined significance in postmenopausal women. Cancer. 2001;93:1-7. [CrossRef]

12. DeSimone CP, Day ME, Tovar MM, Dietrich CS 3rd, Eastham ML, Modesitt SC. Rate of pathology from atypical glandular cell Pap tests classified by the Bethesda 2001 nomenclature. Obstet Gynecol. 2006;107:1285-91. [CrossRef]

13. Tam KF, Cheung AN, Liu KL, et al. A retrospective review on atypical glandular cells of undetermined significance (AGUS) using the Bethesda 2001 classification. Gynecol Oncol. 2003;91:603-7. [CrossRef]

14. Zhao C, Florea A, Onisko A, Austin RM. Histologic followup results in 662 patients with Pap test findings of atypical glandular cells: results from a large academic womens hospital laboratory employing sensitive screening methods. Gynecol Oncol. 2009;114:383-9. [CrossRef]

15. Scheiden R, Wagener C, Knolle U, Dippel W, Capesius C. Atypical glandular cells in conventional cervical smears: incidence and follow-up. BMC Cancer. 2004;19:4-37. [CrossRef]

16. Hammoud MM, Haefner HK, Michael CW, Ansbacher R. Atypical glandular cells of undetermined significance. Histologic findings and proposed management. J Reprod Med. 2002;47:266-70.

17. Schnatz PF, Guile M, O’Sullivan DM, Sorosky JI. Clinical significance of atypical glandular cells on cervical cytology. Obstet Gynecol. 2006;107:701-8. [CrossRef]

18. Sharpless KE, Schnatz PF, Mandavilli S, Greene JF, Sorosky JI. Dysplasia associated with atypical glandular cells on cervical cytology. Obstet Gynecol. 2005;105:494-500. [CrossRef]

19. Massad LS, Einstein MH, Huh WK, et al. 2012 updated consensus guidelines for the management of abnormal cervical cancer screening tests and cancer precursors. J Low Genit Tract Dis. 2013;17(suppl 1):S1-S27. [CrossRef]

20. Insinga RP, Glass AG, Rush BB. Diagnoses and outcomes in cervical cancer screening: a population-based study. Am J Obstet Gynecol. 2004;191:105-13. [CrossRef]

21. Philip Castle;Barbara Fetterman;Nancy Poitras;Thomas Lorey;Ruth Shaber;Walter Kinney. Relationship of Atypical Glandular Cell Cytology, Age, and Human Papillomavirus Detection to Cervical and Endometrial Cancer Risks. Obstetrics \& Gynecology. 2010;115(2):243-8. [CrossRef]

22. Reed SD, Newton KM, Clinton WL, et al. Incidence of endometrial hyperplasia. Am J Obstet Gynecol. 2009;200:678.e1-6. [CrossRef]

23. Kumar N, Gupta R, Gupta S. Glandular cell abnormalities in cervical cytology: What has changed in this decade and what has not?.Eur j Obstet Gynecol Reprod Biol. 2019;240:68-7369. [CrossRef]

24. Norman İ, Hjerpe A, Dillner J. Risk of high-grade lesions after atypical glandular cells in cervical screening: a population-based cohort study. BMJ Open. 2017;7(12):e017070. [CrossRef]

25. Lepe M, Eklund CM, Quddus MR, Paquette C. Atypical glandular cells: Interobserver variability according to clinical management. Acta Cytologica. 2018;62(5-6):397-404. [CrossRef] 